\title{
Implementasi Pembelajaran Yang Efektif Bagi Siswa Madrasah Ibtidaiyah
}

\author{
Anisya Fitriani \\ Institut Agama Islam Negeri (IAIN) Kudus \\ anisyaloveicha@gmail.com
}

\begin{abstract}
Learning is an obligation for every believer to gain knowledge in order to improve the degree of life for them. To be able to absorb optimal learning, the application of effective learning is needed. This paper aims to provide information to educators on the effective learning concept, the concept of apperception and how to do apperception in creating effective learning. The apperception conducted in the early stages of learning is generally considered to be a small thing and sometimes forgotten that many learning activities leads to failure. The apperception can create effective learning because the apperception can lead learners to condition (zone) alpha, which is the best condition for learning so that learners more easily absorb the lesson material. The research method used is a qualitative method. The expected results of this paper are the achievement of effective learning for students so that the learning process can be optimized.
\end{abstract}

Keywords: Effective Learning and Apperception Concept

\begin{abstract}
Abstrak : Belajar merupakan kewajiban bagi setiap orang yang beriman agar memperoleh ilmu pengetahuan dalam rangka meningkatkan derajat kehidupan bagi mereka. Untuk dapat menyerap pelajaran yang optimal maka dibutuhkan penerapan pembelajaran yang efektif. Tulisan ini bertujuan untuk memberikan informasi kepada pendidik tentang konsep pembelajaran efektif dan konsep apersepsi dalam menciptakan pembelajaran efektif. Apersepsi yang dilakukan pada tahap awal pembelajaran pada umumnya dianggap hal kecil dan terkadang terlupakan sehingga banyak kegiatan pembelajaran bermuara pada kegagalan. Apersepsi dapat menciptakan pembelajaran efektif karena apersepsi dapat mengantar peserta didik pada kondisi (zona) alfa, yaitu kondisi terbaik untuk belajar sehingga peserta didik lebih mudah menyerap materi pelajaran. Metode penelitian yang dipakai adalah metode kualitatif. Adapun hasil yang diharapkan dari tulisan ini adalah dapat tercapainya pembelajaran yang befektif terhadap siswa sehingga proses pembelajaran dapat optimal.
\end{abstract}

Kata Kunci: Pembelajaran Efektif, Konsep Apersepsi 


\section{PENDAHULUAN}

Pendidikan merupakan kunci kemajuan dan peradaban suatu bangsa. Semakin baik kualitas pedidikan yang diselenggarakan oleh suatu masyarakat atau bangsa, maka akan diikuti dengan semakin baik pula kualitas sumber daya masyarakat atau bangsa tersebut yang kemudian melahirkan peradaban bernilai tinggi yang dibangun di atas fondasi ilmu pengetahuan. Pendidikan senantiasa menjawab kebutuhan masyarakat dan tantangan yang muncul di kalangan masyarakat, sebagai konsekuensi dari suatu perubahan melalui pendidikan dan pengajaran di sekolah maupun non formal.

Oleh sebab itu pemerintah sangat mengharapkan pendidikan di Indonesia benar-benar menjadi bermutu agar memperoleh hasil yang sesuai dengan keinginan, yaitu tercetaknya generasi penerus bangsa yang mampu bersaing dalam kehidupan dunia. Pada saat ini pendidikan di Indonesia didominasi oleh kelas yang berfokus pada guru sebagai sumber utama pengetahuan. Metode yang menjadi pilihan dalam strategi belajar adalah metode ceramah. Siswa hanya sebagai pendengar dan hanya menerima apa yang disampaikan oleh guru sehingga pengetahuan awal siswa sering terabaikan. Apa yang diajarkan guru adalah yang tercantum dalam kurikulum dan buku materi tanpa ada pengembangan dari guru. Guru hanya mentransfer ilmu-ilmu untuk dihafalkan, bukan untuk dipahami. Akibatnya ilmu yang dimiliki siswa nantinya hanya dapat diingat sesaat (short term memory).

Sangatlah penting sebelum memulai gagasan sistemi apapun bagi tim guru maupun pengajar, untuk bersedia belajar, dan pada gilirannya, melatih dan mendukung setiap proses pembelajaran yang berfokus pada gagasan sekolah. Kesadaran akan sifat dasar pemetaan kurikulum dan kebutuhan pelaksanaan termasuk pemberitahuan pada anggota dewan sekolah, pengawas, dan guru pada setiap sekolah. Hal ini akan dicapai dengan baik dengan menetapkan kabinet pemetaan kurikulum dari sebuah wilayah dan anggota dewan pemetaan kurikulum sekolah. Sekali gagasan sistematik telah dimulai, jumlah yang tepat untuk waktu pelatihan yang memadai dan pengaplikasian akan berdampak pada keberhasilan pendidikan. Di samping bertujuan untuk mendukung guru dengan tepat, seorang administrator perlu menunjukkan perubahan struktur yang berpotensi untuk memastikan pengembangan profesional dan waktu pengerjaan kurikulum yang terkoordinasi dengan strategis. 
Berdasarkan paparan di atas maka bahasan dalam tulisan ini adalah makna, dasar dan prinsip kurikulum, konsep dasar pembelajaran serta pembelajaran yang efektif bagi siswa Madrasah Ibtidaiyah dan kontribusi kurikulum dalam mewujudkan pembelajaran yang efektif.

\section{PEMBAHASAN}

\section{Pengertian, Dasar dan Prinsip Kurikulum}

Kata kurikulum berasal dari Bahasa Yunani, yaitu dari kata "currere" yang berarti jarak tempuh lari. Dengan kata lain jarak yang ditempuh oleh seorang pelari dari mulai garis start sampai garis finish. Jadi secara singkat dapat diartikan sebagai sarana pengantar pada tujuan. pada awalnya istilah kurikulum sering digunakan dalam istilah olah raga. Namun pada tahun 1955 mulai digunakan dalam bidang pendidikan. ${ }^{1}$

Sedangkan menurut pandangan baru atau modern, kurikulum tidak hanya sekedar rencana pelajaran. Kurikulum diartikan sebagai sesuatu yang nyata yang terjadi dalam proses pendidikan di sekolah, baik di dalam kelas, di luar kelas, dan sebagainya yang diorganisir oleh sekolah.

Menurut Abdul Mujib kurikulum dimaknai sebagai perangkat perencanaan dan media untuk menghantarkan lembaga pendidikan dalam mewujudkan tujuan pendidikan yang diinginkan. Sedangkan menurut Ramayulis (mengutip Crow dan Crow mendefinisikan kurikulum sebagai rancangan pengajaran atau sejumlah mata pelajaran yang disusun secara sistemis untuk menyelesaikan suatu program guna memperoleh legalitas dari suatu lembaga yaitu ijazah. ${ }^{2}$

Ahmad Tafsir lebih jauh mengatakan pengertian kurikulum sebagai program dalam mencapai tujuan pendidikan. Lebih lanjut beliau mengatakan pada umumnya isi kurikulum adalah nama-nama pelajaran beserta silabinya atau pokok bahasan. Kurikulum juga mencakup nama-nama kegiatan (kegiatan ekstrakulikuler). ${ }^{3}$

Dalam bukunya Abuddin Nata mengatakan secara harfiah kurikulum berasal dari Bahasa Latin, curriculum yang bermakna bahan palajaran. Sedangkan dalam Bahasa Prancis courier yang bermakna berlari. Kata kurikulum kemudian diadopsi menjadi Bahasa Indonesia dan menjadi istilah yang digunakan untuk

1 Heris Hermawan, Filsafat Pendidikan Islam (Jakarta: Depag RI, 2009), 198

2 Ibid., 200

3 Ibid., 200 
menunjukkan pada sejumlah mata pelajaran yang harus ditempuh untuk mencapai suatu gelar atau untuk memperoleh ijazah. Kata ini juga dapat bermakna sejumlah mata pelajaran yang disiapkan berdasarkan rancangan yang sistematis dan koordinatif dalam rangka mencapai tujuan pendidikan yang ditetapkan ${ }^{4}$

Sedangkan menurut Hasan Langgulung sebagaiman dikutip oleh Abuddin Nata mengatakan bahwa kurikulum adalah sejumlah pengalaman pendidikan, kebudayaan, sosial, olahraga dan kesenian baik dalam sistem pendidikan formal maupun informal. ${ }^{5}$

Berdasarkan berbagai pengertian di atas, kurikulum dapat diartikan sebagai seperangkat rencana dan pengaturan pendidikan atau pengajaran dan hasil pendidikan atau pengajaran yang harus dicapai oleh peserta didik dalam jangka waktu tertentu baik dalam pendidilan formal maupun informal.

Dua orang penulis pendidikan Islam, Al-Syaibani dan Abdul Mujib) menetapkan dasar pokok bagi kurikulum sebagai berikut:

1. Dasar Religi

Pendidikan Islam adalah pendidikan yang berdasarkan agama. Sehingga dasar religi menjadi dasar utama. Dasar ini ditetapkan berdasarkan nilai-nilai Ilahi. Penetapan nilai-nilai tersebut didasarkan pada Islam sebagai agama wahyu yang diturunkan Tuhan untuk umat manusia.

2. Dasar Falsafah

Dasar filosofis menjadi penunjuk arah bagi tujuan pendidikan Islam. Sehingga kurikulum mengandung kebenaransesuai dengan apa yang dikandung oleh pandangan hidup tersebut (Islam).

3. Dasar Psikologis

Dasar psikologis kurikulum menurut pendidikan Islam memandang kondisin peserta didikberada pada dua posisi, yaitu sebagai anak yang hendak dibina dan sebagai pelajar yang hendak mengikuti proses pembelajaran. Dasar ini memberikan landasan dalam perumusan kurikulum yang sejalan dengan perkembangan psikis peserta didik.

4. Dasar sosiologis

Dasra ini berimplikasi pada kurikulum pendidikan supaya kurikulum yang dibentuk hendaknya dapat membantu pengembangan masyarakat. Terutama karena pendidikan berfungsi sebagai sarana transfer of culture (pelestarian kebudayaan), proses sosialisasi individu dan rekonstruksi sosial. 


\section{Dasar organisatoris}

Dasar ini menjadi acuan dalam bentuk penyajian bahan pelajaran. Dasar ini berpijak pada teori psikologi asosiasi yang menganggap keseluruhan sebagai kumpulan dari bagian-bagiannya. Dan juga berpijak pada teori psikologi Gestalit yang menganggap keseluruhan mempengaruhi organisasi kurikulum yang disusun secara sistematis tanpa adanya batas-batas antara berbagai mata pelajaran. ${ }^{6}$

Dalam penyusunan kurikulum, terdapat prinsip-prinsip yang perlu diperhatikan dalam kurikulum pendidikan Islam. Menurut Ramayulis tiga belas prinsip-prinsip kurikulum pendidikan Islam adalah sebagai berikut:

1. Prinsip kurikulum pendidikan Islam berasaskan ajaran dan nilai-nilai Islam. Oleh karena itu, setiap yang berkaitan dengan kurikulum, termasuk falsafah, tujuan dan kandungan, metode, system dan lembaga pendidikan berdasarkan pada asas Islam.

2. Prinsip mengarahkan kepada tujuan dan aktivitas dalam kurikulum diarahkan untuk mencapai tujuan yang telah dirumuskan sebelumnya.

3. Prinsip imtegritas Antara mata pelajaran, pengalaman-pengalaman dan aktiitas yang terkandung dalam kurikulum disesuaikan dengan kebutuhan peserta didik dan masyarakat.

4. Prinsip relevansi adalah adanya kesesuaian pendidikan dengan lingkungan sekitar peserta didik, sesuai dengan kebutuhan jaman dan penyesuaian dengan lapangan pekerjaan yang dibutuhkan.

5. Prinsip fleksibiilitas adalah tempat untuk menyesuaikan diri dengan lingkungan dalam kebebasan bertindak yang berorientasi pada program pendidikan maupun dalam mengembangkan program pengajaran.

6. Prinsip integritas adalah kurikulum yang dapat menghasilkan manusia seutuhnya, manusia yang dapat menggabungkan kemampuan dzikir dan pikir dan manusia yang dapat menyelaraskan struktur kehidupan dunia dan akhirat.

7. Prinsip efisiensi adalah kurikulum yang dapat memanfaatkan waktu, tenaga, dana dan sumber lain secara cermat dan tepat, memadai dan dapat memenuhi harapan.

8. Prinsip kontinuitas dan kemitraan dalah bagaimana susunan kurikulum yang terdiri dari bagian yang berkelanjutan dengan kaitan-kaitan kurikulum lainnya, baik secara vertical maupun secara horizontal.

9. Prinsip individualitas adalah bagaimana kurikulum memperhatikan perbedaan pembawaan dan lingkungan anak pada umumnya yang meliputi seluruh aspek pribadi anak didik, seperti perbedaan jasmani, watak inteligensi, bakat serta kelebihan dan kekurangan. 
10. Prinsip kesamaan memperoleh kesempatan dan kebebasan dalam memberdayakan semua peserta didik dalam memperoleh pengetahuan, keterampilan dan sikap sangat diutamakan.

11. Prinsip kedinamisan adalah kurikulum itu tidak statis tetapi dapat mengikuti perkembangan ilmu pengetahuan dan perubahan sosial.

12. Prinsip keseimbangan adalah bagaimana kurikulum dapat mengembangkan sikap dan potensi peserta didik secara harmoni.

13. Prinsip efektivitas adalah agar kurikulum dapat menunjang efektifitas guru dalam mengajar dan peserta didik dalam belajar.

\section{Pengertian dan prinsip Pembelajaran}

Pembelajaran berasal dari kata dasar "belajar" yang memiliki arti suatu bentuk usaha untuk memperoleh kepandaian atau ilmu. Dalam belajar seseorang akan memperoleh pengertian yang lebih luas serta mengumpulkan pengalaman untuk menghadapi situasi yang akan datang. Karena proses belajar adalah proses jangka panjang. ${ }^{8}$

Sedangkan pembelajaran adalah segala aktifitas atau kegiatan dalam proses pendidikan atau belajar mengajar baik yang mencakup tentang perencanaan sampai tujuan untuk mendapatkan efektifitas pembelajaran. Pembelajaran terkait dengan bagaimana (how do) membelajarkan siswa atau bagaimana membuat siswa dapat belajar dengan mudah dan terdorong oleh kemauannya sendiri untuk mempelajari apa (what to) yang teraktualisasikan dalam kurikulum sebagai kebutuhan (needs) peserta didik.

Menurut Bagne dalam Abdul Rachman Shaleh mengungkapkan bahwa pembelajaran diartikan sebagai acara dari peristiwa eksternal yang dirancang oleh guru guna mendukung terjadinya kegiatan belajar yang dilakukan siswa. Kegiatan pembelajaran lebih menekankan kepada semua peristiwa yang dapat berpengaruh secara langsung kepada efektivitas belajar siswa, dengan kata lain pembelajaran adalah upaya guru agar terjadi peristiwa belajar yang dilakukan siswa $^{10}$

Dengan demikian dapat disimpulkan bahwa pembelajaran adalah sebuah usaha yang dilakukan untuk memudahkan proses internal yang berlangsung

\footnotetext{
7 Ibid., 203

8 Abdul Manab, Manajemen Kurikulum Pembelajaran di Madrasab (Yogyakarta: Kalimedia, 2015), 163

9 Muhaimin, Paradigma Pendidikan Islam (Bandung: Remaja Rosdakarya, 2001), 145

10 Abdur Rachman Shaleh, Madrasah dan Pendidikan Anak Bangsa (Jakarta: Raja Gratindo Perdasa, 2004), 217
} 
ketika seseorang belajar, serta upaya untuk mewujudkan pembelajaran yang sesuai dengan kemampuan peserta didik agar mencapai tujuan tertentu.

Makna pembelajaran secara konseptual menurut Diknas adalah konsep belajar yang membantu guru mengaitkan antara materi yang diajarkan dengan situasi dunia nyata dan mendorong siswa membuat hubungan antara pengetahuan yang dimilikinya dengan perencanaan dalam kehidupan mereka sehari-hari.

Dari konsep belajar dan pembelajaran dapat diidentifikasikan prinsipprinsip belajar dalam pelaksanaan pembelajaran sebagai berikut: ${ }^{11}$

1. Prinsip Kesiapan (Readiness)

Kesiapan belajar adalah kondisi fisik-psikis (jasmani-mental) individu yang memungkinkan subjek dapat melakukan belajar. Biasanya, kalau beberapa taraf persiapan belajar telah dilalui peserta didik maka ia siap untuk melaksanakan suatu tugas khusus. Peserta didik yang belum siap melaksanakan suatu tugas dalam belajar akan mengalami kesulitan atau malah putus asa tidak mau belajar. Kesiapan belajar meliputi kematangan dan pertumbuhan fisik, psikis, inteligensi, latar belakang pengalaman, hasil belajar, motivasi, persepsi dan faktor-faktor lain yang memungkinkan seseorang dapat belajar.

2. Prinsip Motivasi (Motivation)

Motivasi dapat diartikan sebagai tenaga pendorong atau penarik yang menyebabkan tingkah laku kea rah suatu tujuan tertentu. Ada tidaknya motivasi dalam peserta didik dapat diamati dari tingkah lakunya. Berikut tanda-tanda bila seorang peserta didik memiliki motivasi:

a. Bersungguh-sungguh, menunjukkan minat, mempunyai perhatian dan rasa ingin tahu yang kuat untuk ikut serta dalam kegiatan belajar.

b. Berusaha keras dan memberikan waktu yang cukup untuk melakukan kegiatan belajar

c. Terus bekerja sampai tugas-tugas belajar diselesaikan.

3. Prinsip Perhatian

Dalam proses pembelajaran, perhatian merupakan faktor yang besar pengaruhnya. Apabila peserta didik memiliki perhatian yang besar mengenai materi yang disajikan atau dipelajari, peserta didik dapat memilih stimuli yang relevan untuk diproses lebih lanjut. 
4. Prinsip Persepsi

Untuk membentuk persepsi yang akurat mengenai stimuli yang diterima serta mengembangkannya menjadi suatu kebiasaan, perilaku ada latihanlatihan dalam bentuk dan kondisi situasi yang bermacam-macam agar peserta didik tetap dapat mengenal pola stimuli tersebut, meskipun disajikan dalam bentuk yang berbeda.

5. Prinsip Retensi

Retensi adalah apa yang tertinggal dan dapat diingat kembali setelah seseorang mempelajari sesuatu. Menurut Thomburg ada beberapa hal yang dapat meningkatkan retensi belajar peserta didik, diantaranya:

a. Isi pembelajaran yang bermakna.

b. Benda yang jelas/kongkret

c. Pembelajaran yang bersifat konseptual atau serangkaian kata.

6. Prinsip Transfer

Transfer merupakan suatu proses dimana sesuatu yang pernah dipelajari, dapat mempengaruhi proses dalam mempelajari sesuatu yang baru. Dengan demikian, transfer berarti pengaitan pengetahuan yang sudah dipelajari dengan pengetahuan yang baru dipelajari. Pengetahuan atau keterampilan yang diajarkan di sekolah selalu diasumsikan atau diharapkan dapat dipakai untuk memecahkan masalah yang dialami dalam kehidupan atau dalam pekerjaan yang dihadapi kelak. Transfer belajar atau transfer latihan berarti aplikasi atau pemindahan pengetahuan, keterampilan, kebiasaan, sikap, atau respon-respon lain dari suatu situasi ke dalam situasi yang lain.

\section{Pembelajaran yang Efektif bagi Siswa Madrasah Ibtidaiyah}

Beberapa ahli pembelajaran mengemukakan pandangannya yang hampir sama tentang pembelajaran efektif. Misalnya Yusuf Hadi Miarso memandang bahwa pembelajaran yang efektif adalah pembelajaran yang menghasilkan belajar yang bermanfaat dan terfokus pada siswa (student centered) melalui penggunaan prosedur yang tepat. Definisi ini mengandung arti bahwa pembelajaran yang efektif terdapat dua hal penting, yaitu terjadinya belajar pada siswa dan apa yang dilakukan oleh guru untuk membelajarkan siswanya.

Menurut Wotruba dan Wright berdasarkan pengkajian dan hasil penelitian, mengidentifikasi tujuh indikator yang dapat menunjukkan pembelajaran yang efektif, antara lain: 


\section{Pengorganisasian materi yang baik}

Pengorganisasian adalah bagaimana cara mengurutkan materi yang akan disampaikan secara logis dan teratur, sehingga dapat terlihat kaitan yang jelas antara topik satu dengan topik lainnya selama pertemuan berlangsung. Pengorganisasian materi terdiri dari perincian materi, urutan materi dari yang mudah ke yang sukar, kaitannya dengan tujuan.

Faktor lain yang perlu dipertimbangkan dalam penyajian materi adalah bagaimana kemampuan daya serap peserta didik. Daya serap tersebut bertalian erat dengan motivasi dan kesiapan belajar mereka. Motivasi peserta didik dipengaruhi oleh minat dan perhatian, yaitu hubungan materi pelajaran dengan harapan dan kesiapan belajar sebelumnya.

Kesiapan belajar individu ditentukan oleh penguasaan pengetahuan yang telah dipelajari sebelumnya, keterampilan membaca dan mendengar, tingkat pendidikan yang telah dicapai, dan tingkat kesulitan materi. Pengorganisasian materi juga mencakup faktor penunjang lainnya yang digunakan selama proses penyajian. Faktor penunjang tersebuit Antara lain yaitu penggunaan media, sikap, gerak-gerik mengajar, dan cepat lambat penyajian.

\section{Komunikasi yang efektif}

Komunikasi yang efektif dalam pembelajaran mencakup penyajian yang jelas, kelancaran berbicara, interpretasi gagasan abstrak dengan contohcontoh, kemampuan wicara yang baik (nada, intonasi, ekspresi) dan kemampuan untuk mendengar. Jenis komunikasi lain yang sangat penting adalah komunikasi interpersonal. Bagi seorang guru, membangun suasana hangat dengan para siswa dan antara sesame siswa sangatlah penting.

3. Penguasaan dan Antusiasme terhadap materi pelajaran

Seorang guru dituntut untuk menguasai materi pelajaran dengan benar, jika telah menguasainya maka materi dapat diorganisasikan secara sistematis dan logis. Untuk dapat mengetahui sejauh mana guru dapat menguasai materi dengan baik, dapat dilihat dari pemilihan buku-buku wajib dan bacaan, penentuan topik pembahasan, pembuatan ikhtisar, pembuatan bahan sajian dan yang paling dapat dilihat dengan jelas adalah bagaimana guru dapat dengan tepat menjawab pertanyaan dari siswanya.

4. Sikap Positif terhadap siswa

Sikap positif terhadap siswa dapat ditunjukkan, baik kepada kelas kecil maupun kelas besar. Dalam kelas kecil ditunjukkan dengan cara memberikan perhatian pada orang per orang, sedangkan dalam kelas besar diberikannya kepada kelompok yang mengalami kesulitan. Bantuan kepada para siswa sebaiknya diberikan apabila mereka sudah berusaha sendiri, tetapi kemudian kurang berhasil. Bantuan seperti ini bukan berarti memecahkan masalah yang 
dihadapi siswa, melainkan memberikan saran tentang jalan keluarnya, memberikan dorongan dan membangkitkan motivasi.

5. Pemberian Nilai yang Adil

Sejak dari awal pelajaran, siswa dapat diberitahu berbagai macam penilaian yang akan dilakukan, seperti tes formatif, makalah, proyek, tes akhir, dan pertanyaan lainnya yang mempunyai kontribusi terhadap nilai akhir. Keadilan dalam pemberian nilai tercermin dari adanya:

a. Kesesuaian soal tes dengan materi yang diajarkan merupakan salah satu tolak ukur keadilan;

b. Sikap konsisten terhadap pencapaian tujuan pelajaran;

c. Usaha yang dilakukan siswa untuk mencapai tujuan;

d. Kejujuran siswa dalam memperoleh nilai;

e. Pemberian umpan balik terhadap hasil pekerjaan siswa.

6. Keluwesan dalam Pendekatan Pembelajaran ${ }^{12}$

Keluwesan dalam pendekatan pembelajaran dapat tercermin dengan adanya kesempatan waktu yang berbeda diberikan kepada siswa yang memang mempunyai kemampuan yang berbeda. Kepada siswa yang mempunyai kemampuan yang rendah diberikan kesempatan untuk memperoleh tambahan waktu dalam kegiatan remedial. Sebaliknya, kepada siswa yang mempunyai kemampuan diatas rata-rata diberikan kegiatan pertanyaan. Dengan demikian, siswa memperoleh pelayanan yang sesuai dengan kemampuan mereka.

7. Hasil Belajar Siswa yang baik

Memberikan penilaian terhadap hasil belajar siswa merupakan kewajiban seorang guru dan mutlak dilakukan. Dikatakan kewajiban bagi setiap guru karena pada akhirnya guru harus dapat memberikan informasi kepada lembaga atau siswanya. Petunjuk keberhasilan belajar siswa dapat dilihat bahwa siswa tersebut menguasai materi pelajaran yang diberikan. Namun, karena kemampuan siswa yang bervariasi menyebabkan tidak semua siswa dapat menguasai materi secara tuntas. Kunci pokok untuk memperoleh ukuran dan data hasil belajar adalah dengan menetapkan indikator (petunjuk adanya prestasi tertentu) dikaitkan dengan prestasi yang akan diukur. ${ }^{13}$

\section{Kontribusi Kurikulum dalam Mewujudkan Pembelajaran yang Efektif.}

Keberhasilan dalam proses pembelajaran di dalam kelas memang tidak semata tergantung kepada guru, tetapi melibatkan banyak faktor, diantaranya keaktifan siswa, tersedianya fasilitas belajar, kenyamanan dan keamanan ruangan

12 Ibid., 189

13 Hamzah B. Uno, Belajar dengan Pendekatan PAILKEM (Jakarta: Remaja Rosdakarya, 2011), 174 
kelas dan beberapa faktor lainnya, kendati memang keberadaan guru merupakan faktor penentu utama dalam menciptakan kondisi pembelajaran yang efektif. Dalam mewujudkan kondisi pembelajaran yang efektif, berikut langkah-langkah yang dapat dilakukan antara lain ialah: melibatkan siswa secara aktif, menarik minat dan perhatian siswa, membangkitkan motivasi siswa, memberikan pelayanan individu siswa, menyiapkan dan menggunakan berbagai media dalam pembelajaran.

Untuk mewujudkan suasana kelas yang dapat mendukung proses belajar mengajar secara efektif yaitu:

a. Memanggil setiap murid dengan namanya

b. Selalu bersikap sopan kepada murid,

c. Memastikan bahwa anda tidak menunjukkan sikap pilih kasih terhadap murid tertentu

d. Merencanakan dengan jelas apa yang anda lakukan dalam setiap pelajaran

e. Mengungkapkan kepada murid-murid tentang apa yang ingin anda capai dalam pelajaran ini

f. Dengan cara tertentu melibatkan setiap murid selama pelajaran

g. Memberikan kesempatan bagi murid untuk saling berbicara

h. Bersikaplah konsisten dalam menghadapi murid-murid.

Untuk menciptakan suasana yang dapat menumbuhkan gairah belajar, meningkatkan prestasi belajar siswa, dan lebih memungkinkan guru memberikan bimbingan dan bantuan terhadap siswa dalam belajar, maka diperlukan pengorganisasian kelas yang memadai. Dalam hal ini akan diuraikan beberapa suasana yang efektif dalam pelaksanaan proses pembelajaran:

1. Suasana belajar yang menyenangkan

Suasana belajar yang menyenangkan membuat pembelajaran akan berjalan efektif, apabila suasana pembelajaran tersebut menyenangkan, peserta didik akan lebih rileks, bebas dari tekanan, aman, menarik, bangkitnya minat belajar, adanya keterlibatan penuh, perhatian peserta didik tercurah, lingkungan belajar yang menarik (misalnya keadaan kelas terang, pengaturan tempat duduk leluasa untuk peserta didik bergerak), bersemangat, perasaan gembira, konsentrasi tinggi. Suasana pembelajaran yang menyenagkan menghindarkan pembelajaran yang tidak efektif, karena peserta didik tidak tertekan, perasaan terancam, perasaan menakutkan, merasa tidak berdaya, tidak bersemangat, malas/tidak berminat, jenuh/bosan, suasana pembelajaran monoton, pembelajaran tidak menarik siswa. 


\section{Suasana bebas}

Suasana bebas atau terbuka (permisif) merupakan kebebasan bagi siswa dalam berbicara dan atau berpendapat sesuai dengan tujuan dari proses pembelajaran, sehingga dengan hal tersebut siswa tidak akan merasakan tekananan, adanya rasa takut, malu dan lainnya terhadap guru maupun sesama peserta didik.

3. Pemilihan media pengajaran dan metode yang sesuai

Guru dituntut mampu memiliki dan menggunakan media pengajaran sesuai dengan materi yang akan di sajikan, dituntut mampu menggunakan metode mengajar secara stimulan untuk menghidupkan suasana pengajaran dengan baik.

\section{KESIMPULAN}

Dari bahasan di atas dapat disimpulkan bahwa kurikulum dapat diartikan sebagai seperangkat rencana dan pengaturan pendidikan atau pengajaran dan hasil pendidikan atau pengajaran yang harus dicapai oleh peserta didik dalam jangka waktu tertentu baik dalam pendidikan formal maupun informal. Pada saat penetapan kurikulum haruslah mengindahkan dasar pokok kurikulum antara lain: dasar religi, dasar falsafah, dasar psikologis, dasar sosiologis, dasar organisatoris.

Sedangkan pembelajaran adalah sebuah usaha yang dilakukan untuk memudahkan proses internal yang berlangsung ketika seseorang belajar, serta upaya untuk mewujudkan pembelajaran yang sesuai dengan kemampuan peserta didik agar mencapai tujuan tertentu. Makna pembelajaran secara konseptual menurut Diknas adalah konsep belajar yang membantu guru mengaitkan antara materi yang diajarkan dengan situasi dunia nyata dan mendorong siswa membuat hubungan antara pengetahuan yang dimilikinya dengan perencanaan dalam kehidupan mereka sehari-hari.

Menurut Wotruba dan Wright berdasarkan pengkajian dan hasil penelitian, mengidentifikasi tujuh indikator yang dapat menunjukkan pembelajaran yang efektif, antara lain: pengorganisasian materi yang baik, komunikasi yang efektif, penguasaan dan anttusiasme terhadap materi pelajaran, sikap positif terhadap siswa, pemberian nilai yang adil, keluwesan dalam pendekatan pembelajaran, hasil belajar siswa yang baik.

Sedangkan untuk menciptakan pembelajaran yang efektif seorang guru dapat menempuh langkah-langkah berikut: memanggil setiap murid dengan 
namanya, selalu bersikap sopan kepada murid, memastikan bahwa anda tidak menunjukkan sikap pilih kasih terhadap murid tertentu, merencanakan dengan jelas apa yang anda lakukan dalam setiap pelajaran, mengungkapkan kepada murid-murid tentang apa yang ingin anda capai dalam pelajaran ini, dengan cara tertentu melibatkan setiap murid selama pelajaran, memberikan kesempatan bagi murid untuk saling berbicara, bersikaplah konsisten dalam menghadapi murid-murid.

\section{DAFTAR PUSTAKA}

Abdul Manab, Manajemen Kurikulum Pembelajaran di Madrasah, Yogyakarta: Kalimedia, 2015

Beni Ahmad Saebani, Ilmu Pendidikan Islam, Bandung: CV. Pustaka Setia, 2012

Hamzah B. Uno dan Nurdin Mohamad, Belajar dengan Pendekatan PAILKEM, Jakarta: PT. Bumi Aksara, 2011

Heris Hermawan, Filsafat Pendidikan Islam, Jakarta: Departemen Agama Republik Indonesia, 2009

Muhaimin, Paradigma Pendidikan Islam, Bandung : Remaja Rosdakarya, 2001 
60| Ar-Riayah : Jurnal Pendidikan Dasar Vol. 3, No. 1, 2019

Halaman ini sengaja dikosongkan 